УДК 61:37(477.8)«18/19»

DOI 10.11603/me.2414-5998.2019.2.10362

\author{
I. A. Prokop \\ ORCID 0000-0001-6683-5922 \\ ResearcherID Q-5670-2016 \\ T. V. Savaryn \\ ORCID 0000-0001-8294-6024 \\ ResearcherID Q-5639-2016
}

I. Horbachevsky Ternopil State Medical University

\title{
ESTABLISHMENT AND DEVELOPMENT OF MEDICAL EDUCATION AND SCIENCE IN THE WESTERN UKRAINE (XVIII - XIX CENTURY)
}

\author{
I. А. Прокоп, Т. В. Саварин \\ ДВНЗ «Тернопільський державний медичний університет \\ імені І. Я. Горбачевського МОЗ Украӥни»

\section{СТАНОВЛЕННЯ ТА РОЗВИТОК МЕДИЧНОЇ ОСВІТИ І НАУКИ НА ТЕРЕНАХ ЗАХІДНОЇ УКРАЇНИ (XVIII -XIX СТОЛІТТЯ)}

\begin{abstract}
The research analyses the history of development and organization of medical educational establishments in the Western Ukraine in the second half of XVIII-XIX century.

The article discusses the method of analysing bibliographic catalogues, classification and systematization of primary sources in History of Medicine and Pedagogy, and chronological method that identifies the establishment and development of medical education during different historical periods.

The paper describes the structure of medical education system in the Western Ukraine in the second half of XVIII-XIX century and summarizes available data about professional and scientific activity of the outstanding Ukrainian doctors of this period.

The main characteristics of medical education development in the mentioned historic period are: gradual increase in the number of medical establishments, medical departments, faculties, and students; improvement and transformation of medical personnel education and training.
\end{abstract}

Key words: medical education; Western Ukraine; medical personnel; education; research.

Анотація. У статті проаналізовано історію виникнення та організації навчальних закладів для підготовки медичних працівників на західноукраїнських землях у другій половині XVIII -XIX ст.

У роботі використано бібліографічний метод вивчення бібліотечних каталогів; класифікацію та систематизацію джерел $з$ історії медицини, педагогіки; хронологічний метод, що дозволив проаналізувати особливості становлення і розвитку медичної освіти у різні історичні періоди. Відтворено структуру системи медичної освіти на західноукраїнських землях у другій половині XVIII -XIX ст.; уточнено відомості про професійну та наукову діяльність видатних українських лікарів цього періоду. Визначальними критеріями процесу розвитку медичної освіти можна назвати: поступове зростання мережі закладів медичної освіти, збільшення числа кафедр, збільшення кількості студентів і викладачів у них, розширення змісту навчання, зміну рівня професійної підготовки медиків.

Ключові слова: медична освіта; західноукраїнські землі; медики; навчання; дослідження.

Introduction. Medical education should be regarded as an integral part of the general system of professional training, its current development specifics in particular. At the same time, traditions of health care system and peculiarities of medical education should be taken into account. In this, formation of the medical education includes the study of its historical background in the different regions of Ukraine, XIX - early XX century in particular.

(C) I. A. Prokop, T. V. Savaryn
The history of medical science establishment in Ukraine has long attracted the interest of scholars, in particular T. Burachynsky, S. Verkhratsky, L. Honsyorovsky, B. Kryshtopa, Y. Lukashevych, M. Muzyka, V. Shumovsky, I. Ohiyenko, Y. Ozarkevych, M. Panchyshyn, O. Ruzanova, S. Stazhynsky, I. Shapiro, M. Shehedyn, L. Finkel. Besides, the issue has been studied by contemporary scientists: A. Vykhrushch, L. Klos, V. Kravets, V. Saharda, B. Stuparyk, M. Kushyk. 
The aim of the work is to review the history of emergence and organization of medical training institutions in the Western Ukraine in XVIII-XIX century.

Theoretical framework. The paper reconstructs the structure of medical education system in the Western Ukraine in the second half of XVIII-XIX century. Besides, the information about professional and scientific activity of prominent Ukrainian medics of the period under discussion is specified.

As indicated by numerous evidence, in the second half of XVIII century public health-care in the Western Ukraine was poor. No rural hospital was built in Galicia and Transcarpathia at the time of Austria-Hungary (1771-1918). Of 46 district towns, hospitals were in 27 only. In-patient care was paid-for and mostly unavailable for peasants, the bulk of beds in the hospitals being out of use [2-4].

In fact, there was no state sanitary service and medical training institutions. As evidenced by the researchers of medical history, Austrian health reform (1770) involved Western Ukraine. For the sake of medical care improvement and development of the medical education and science in the Kingdom of Galicia and Lodomeria, the Empress of Austria Maria Theresa appointed Doctor of Medicine Andrey Krupynsky (Decree of 22 December, 1772) a territorial protomedic of Galicia. He was entrusted with the mission of establishing the system of medical service and medical education in the Western Ukraine.

The opening ceremony of Lviv Midwifery Collegium took place on October 1, 1773, the date marking the origin of secondary medical education in the Western Ukraine. Training at the Collegium was free of charge. Furthermore, the listeners were fully provided by the landowners who had directed them to the Collegium. The pupils received one gulden a week from the Governer's Fund. The admitted to the Collegium were physically and mentally fit persons of both sexes, aged 21-30. Naturally, intelligent individuals, exhibiting mercy and love for midwifery, were preferred.

The Collegium study course was within $1-3$ years, alongside with crash midwife courses. This contributed to the improvement of obstetric care in the Kingdom [2].

Under serious shortage of paramedic personnel, many medics were unemployed or engaged in private medical practice. At that time minor hospitals worked without paramedic personnel, whereas in large ones there was one doctor/one paramedic correlation, working conditions being very hard and salary - quite poor. Working as nurses at the clinics of the only medical faculty of Lviv University were nuns without the simplest and basic skills of care-giving [2].

Established in 1784, Lviv medico-surgical school, training midwives, pharmacists, and surgeons was essential for the development of medical education in the Western Ukraine. First, the course of training was 2 years that was followed by 3-year training period since 1833. In 1874-1875 the school was closed. In 1875, an Emperor's school for training midwives was organized in Lviv. Training period at obstetric schools varied from 3-5 months in Transcarpathia to 8 months in Bukovyna, the pupils being taught practical skills $[7,9,13]$.

By the time of transition under Austria reign in 1773, the population of Lviv was 25000 residents, of them 6 doctors only (2 Frenchmen, 1 Italian, 1 Czech, 2 Poles). Apart from the doctors and traditional medics, medical aid to the population of the Western Ukraine was rendered in 1772-1918 by the barbers, surgeons, midwives, medical assistants, sisters of mercy, nurses, i.e. paramedic personnel.

Training of specialists was carried out in different ways: from individual training for barbers, midwives, and nurses - to the study at state and private schools which trained surgeons, midwives, surgeon assistants, and nurses. Organization of the teaching process at the specialized medical schools in various parts of the Western Ukraine was different enough. The Austrian government established state positions of district and city doctors who were supposed to control those involved in medical practice, hygiene, supply of drinking water, to provide epidemic control measures. They were also allowed to act as private medical [4].

In early XX century, there were 3 basic trends in the development of secondary medical education in the Western Ukraine: midwives, nurses and surgeons were trained in Halychyna; midwives only - in Transcarpathia and Bukovyna; surgeon assistants and midwives - in Volyn [8].

Some researchers noted higher training of surgeons and midwives in Halychyna as compared with the other regions. This can be attributed to the fact that the teaching course in the XIX century included 3 basic groups of disciplines: general educational, professionally oriented and special ones. It was not before early XX century that such a level was achieved in Volyn, after educational reform of 1903 in Russia. In Transcarpathia and Bukovyna training of the midwives was mainly practical. It should be mentioned that in Bukovina teaching was in Romanian, in Transcarpathia - in Hungarian or German, in Galicia - in Polish, in Volyn 
- in Russian. Naturally, foreign language manuals (not in Ukrainian) were used. At this, district doctors and hospital managers were mostly appointed the teachers of medical training institutions [8].

L. Y. Klos notes that from the standpoint of education the medics can be divided into 3 groups: group 1 - graduates of universities and academies; group 2 - surgeons with university education; group 3 - "barbers", the latter belonging to professional unions guilds, which provided practical training. It was the barbers that acted as assistants in the surgical operations, performed by professors at the university clinics. Along with the mentioned categories of medics, the population of the medieval Europe was served by the representatives of traditional medicine (healers, bonesetters, bloodletters) [7].

Thus, neither Halychyna nor Transcarpathia had the higher medical school throughout XIX century. It was not before 1894 that a medical faculty was established at the Lviv University, though with restricted access for the Ukrainians (upon request of Jesuits, the university with the medical faculty was opened in Lviv in 1661. However, 2 years later it was closed on demand of the Krakiv University, probably due to fear of competition. The medical faculty was then opened in 1784 and closed again in 1805). Activity of medical faculties was established within educational policies of the empires. During 25 years of the faculty functioning under Austria-Hungary, 544 doctors graduated, of them 40 Ukrainians. During the reign of bourgeois Poland, within $5 \%$ of Ukrainians were allowed to enter the medical faculty of the Lviv University. Regularly, the Ukrainians could work as private practitioners only. Without access to staff positions in clinics and hospitals, they were not able to attain high qualification, not to mention the fact that Ukrainians were not allowed to work in the sphere of research and teaching $[2,3]$.

L. Y. Klos, a researcher of the particular time frame, distinguishes 2 periods in the activity of the institution: 1784-1805 and 1894-1918, which are significantly different in terms of education content as well as teaching forms and methods. Throughout the first period, the faculty trained doctors according to the Austrian program, which was traditional for medieval universities. The study course lasted 7 years, the first 3 dedicated to philosophic studies and the next $4-$ to studying professionally-oriented disciplines (Anatomy, Physiology, Pharmacognosy, Pathology, Natural History for Medics), and special subjects (Surgery, Obstetrics, Ophthalmology Course). The number of students at the medical faculty, then non-prestigious, was limited, thus leading to shortened curriculum and ultimately - to the closure of the faculty.

Within 5 years of the next period (1894-1918) 14 departments were established and new subjects were introduced (Biological Chemistry, Histology and Embryology, Pathological Anatomy, Hygiene, Dermatovenereal Diseases, Paediatrics, Neuropsychiatric Disorders, Otorhinolaryngology, Dentistry). The teaching process changed too, philosophic faculty having progressed from the preparatory one to quite equitable to the others. The study course at the medical faculty lasted 5 years according to the new curriculum, similar to that at the Warsaw University [7].

Higher pharmaceutical education began to develop in Lviv after the Emperor of Austro-Hungary FranzJosef I had signed the decree on the establishment of Pharmaceutical Department at the Philosophic Faculty of the Lviv University in 1854-1855 academic year. Classes were held by the professors of philosophic faculty and medico-surgical unit. Pharmacists were regarded as non-traditional listeners, and along with compulsory disciplines they were advised to attend classes in natural subjects. In 1889, pharmaceutical education in Austria was reformed. According to the reform, assistant practice was cancelled and study at the university was to be preceded by the admission test. Six years of gymnasium was introduced as sine qua non for admission of an apprentice to the pharmacy [4].

Brief review of the state of medical education in Volyn, Halychyna, Transcarpathia, and Bukovina by today's researchers makes it possible to confirm the increase in the number of educational institutions and in their variety (midwife schools, doctor's assistant schools, medical faculty and medical collegium). Besides, growing requirements to the entrants were issued (only literate were admitted); theoretical and practical training were combined. In Galicia, Lviv in particular, most of scientific medical courses were held by highly-reputed medics-scientists, professors that surely contributed to the increase in the graduates' educational level.

Up to 1918, preference was given to verbal methods of teaching (lectures, narration, explanations), whereas visual aids (illustration, demonstration) were used less frequently. Practical work and exercises were prevailing then, laboratory work being at a rudimentary stage. Lectures accounted for about a half of teaching process, being the only organizational form for medical history and philosophy. It was then that the cycles of practical classes on the subject of special courses began to be introduced. Practical and laboratory classes were 
held in appropriately equipped rooms and laboratories (workshops) with proper set of charts, copies of scientific papers, corpses, laboratory animals, as well as devices (microscopes, electrocardiographs, photo-and $\mathrm{X}$-ray apparatus, myographs. At that period, clinical disciplines were differentiated and specialized, thus resulting in the separation of pulmonology, cardiology, gastroenterology, nephrology, endocrinology, etc. from the course of internal diseases [7].

Teaching was carried out on the basis of visualization, scientific character, systemacy, consistency, thoroughness, and activity. Learning tools were supplemented by the manuals in German and Polish. Introduction of students' duties at the clinics was indicative of growing attention to the formation of practical skills. "Rigoros" (state exam) and short test were used for current monitoring of learning achievements, whereas rigoros in the presence of examination board was practised for the final monitoring. Education was not free of charge. Opening of regular supplementary courses for the doctors was another essential innovation [7].

Up to the early XX century, in the Western Ukraine there were no Ukrainian-speaking institutions of medical education. For the purpose of meeting health care challenges and development of national medical science, Galician doctors of Ukrainian origin began to establish doctors' societies. Among the major factors of establishing professional societies of Ukrainian doctors were the need for providing high-skilled medical personnel for the natives of the western Ukraine; organization of treatment and preventive practice, hygiene and health education. On December 2, 1867, Lviv medics established the Society of Galician doctors, first numbering 47 persons and then joined by the doctors from district villages. Along with the statute activity, the society was also involved in the research work. In 1908, the similar society was formed in Drohobych. Following the example, pharmacists, balneologists and dentalprothetists organized societies to uphold their professional rights. In 1892, mathematic-naturalmedical section of T. Shevchenko scientific society had been founded that grew into the Doctor's commission in 1898. In 1900, "Lviv Polyclinic" society was founded for joint scientific and medical activity. It was a charitable organization as the doctors were committed to providing free medical care for low-income patients and supplying them with discount drugs. "Lviv Polyclinic" had an outpatient clinic and a laboratory. Scientific activity was carried out through holding scientifically-practical conferences and issuing medical periodicals, thus providing concord of theoreti- cal and practical medicine [1, 7]. In 1903, "People’s Hospital" society was established, later transforming into Ukrainian Medical Society (1910). Headed by Y. I. Ozarkevych, the society carried out training of young medical personnel and propagated basic medical knowledge; developed medical terminology in Ukrainian; cooperated with similar organizations abroad; upheld the rights of Ukrainian population in Vienna and on the ground; provided hygienic education. Since 1912, a journal "Zdorovle" ("Health”) was issued with Y. I. Ozarkevychm as the editor and the author of most papers $[6,10,11]$.

Professor of medial chemistry in Prague I. Ya. Horbachevsky, an outstanding Ukrainian scientist, was elected the Honorary Chairman of the society.

I. Ya. Horbachevsky (1854-1942) was born in the village of Zarubyntsy, now Zbarazh district of Ternopil region. During 35 years he had been managing the Department of Biochemistry at the Charles University in Prague. After the World War I he was the rector of the Ukrainian University in Prague; since 1925 - an academician of the academy of Sciences of the Ukrainian Soviet Socialist Republic. I. Horbachevsky was the first who synthesized uric acid from urea and glycine, and discovered sources and ways of its formation in the body. Besides, he discovered the enzyme named xanthine oxidase. He was also credited with the creation of a large school of Czech biochemists. Forced to work in the alien country, he never forgot his natives, studied the issue of Podillia population nutrition, developed Ukrainian chemical terminology, and wrote the first biochemistry textbook in Ukrainian [4, 5].

At the same time, Ivan Horbachevsky implemented the national idea as an active member of the societies "Hromada" and "Sich", and from 1899 - full member of T. Shevchenko scientific society [12]. He contributed much to the organization and establishment of the Ukrainian Medical Society on the basis of T. Shevchenko scientific society, and was elected the first honorary chairman. Ivan Horbachevsky actively cooperated with Ukrainian scientists and medical practitioners in Lviv. In 1911-1918 he was the chairman of mathematicnatural-medical section and contributed greatly to the project of establishing Ukrainian scientific terminology in the fields of medicine and chemistry $[1,4,5]$.

Foundation of unprecedented in the world specialized Ministry of People's Health as a separate structural unit of the Austro-Hungarian government was another outstanding event both in Ivan Horbachevsky's life and Ukrainian as well as European medicine. Following Ukrainian pattern, similar ministries were 
organized in England, France, Rzeczpospolita II, and other countries. Indeed, Ivan Horbachevsky was the original author of the idea and its practical executor, as he developed the project of the Ministry and became the first minister (July 1918 - late October 1918) [1, 5]. He had the previous experience in this activity (membership in the territorial sanitary council in Prague and superior sanitary council in Vienna (1906). Naturally, Ivan Horbachevsky spared no effort in the establishment of Ukrainian free university in 1921. He headed the university in 1923 [1]. With the outbreak of World War I society activity and journal issuing ceased.

An impressive chapter in the development of new Ukrainian medicine was written by its founder doctor Yevhen Ozarkevych, born on May 8, 1861 in the family of a clergyman, in the village of Beleluya, Snyatyn district. Father, Ivan Ozarkevych - priest and public figure who spoke several European languages and was an ambassador (deputy) of the territorial seim, and later - Vienna parliament. Mather - Teofilia (née Okunevska). Ozarkevych’s home was a centre of the Ukrainian culture indeed, close friends and relatives calling it "Rus Athens". It was not random for Ozarkevych family to be a classic example of genuine Ukrainian elite: Yevhen's brother Longin was a lawyer in Horodok near Lviv. In 1939, already aged and sick, he was arrested by the Soviets and transported to Russia together with his daughter and son-in-law, their fate remaining unknown to this day. His brother Volodymyr Ozarkevych, a priest in Beleluya, married Olha Roshkevych (Ivan Franko's fiancée); sister Natalia married Teofil Kobrynsky and then became a writer and social activist; sister Yeronima became related with the family of Solomiya Krushelnytska and was known as a collector of folk art works. In 1925, she moved to the Soviet Ukraine and was probably repressed in 1937, her fate remaining unknown $[1,3,6]$.

Yevhen Ozarkevych - energetic, capable, displaying outstanding organizational skill, highly cultured erudite with a good command of foreign and classical languages - had a relentless desire to work for Ukraine. During his active years (he died on September 21, 1916) his contribution to the development of Ukrainian science and medicine, as well as to the medical and social care for the most vulnerable social groups was equal to the contribution of a few generations of experts. His record includes authorship of the very first scientific medical works in Ukrainian, membership in T. Shevchenko scientific society and management of its medical commission, foundation and editing of "Doctor's Collection", the first medical edition in Ukrainian, compilation of scientific medical terminology in Ukrainian, authorship of a number of scientific and political publications, foundation and editing of the first Ukrainian sanitary and hygienic journal “Zdorovle” ("Health”), initiation and management (until the end of his life) of the first Ukrainian outpatient clinic "People's hospital", representation of Ukrainian doctors at a series of international scientific congresses, active participation in "Prosvita", acting as a senior sanitary advisor and membership in the Supreme Health Council in Vienna $[1,6]$. In his preface to the monthly "Zdorovle" Yevhen Ozarkevych wrote: "Genuinely cultural people should have all the branches of human knowledge gathered in his written records". He emphasized the importance of the public support for the development of hygienic education and headed Lviv Prosvita for a long time. Under totalitarianism, the activity of this true patriot, doctor, scientist, and educator was hushed up [4].

Yevhen Ozarkevych was the first who published medical works on the laboratory examination of hepatic diseases and malaria diagnostics in Ukrainian, and the first who started teaching medical disciplines in Ukrainian. He was also the first to raise the question of opening Ukrainian medical faculty on the basis of "People's hospital" in Lviv; to publish essays and reviews of the papers from new European journals. Besides, he published a series of valuable papers on hygiene and balneology, and contributed to the foundation of the first Ukrainian sanatorium for tuberculosis patients in Pidlyute, thus initiating Ukrainian balneology. His book "Epidemic diseases" laid foundation of teaching on infectious diseases in the Ukrainian medicine [3]. Some of his initiatives were much ahead of time. According to many researchers, public health system in AustroHungary, though largely imperfect, spurred origin and development of Ukrainian medicine and formation of medical intellectuals, the latter being also promoted by the establishment of a series of medical institutions, professional and scientific societies [1].

Conclusions and Prospects for Research. Thus, development of medical education in the Western Ukraine in the second half of XVIII - sixties of $\mathrm{XX}$ century was both complicated and contradictory, and influenced by many interrelated factors: specifics of historical, political and socio-economic development, experience of the European countries, reorganization of educational and health care institutions in line with the internal policy, opening of state and private educational institutions, activity of various medical 
societies. Determining criteria of medical education development were: growing network of medical education establishments, as well as growing number of departments, students and instructors; expansion of education content; improved professional skill of medics; tightened requirements for the entrants (only literate were admitted); combined theoretical and practical training. In Halychyna and Lviv in particular, most of medical courses were held by famous medical scientists that contributed to the increase

\section{List of literature}

1. Білавич I. В. Становлення і розвиток громадської системи охорони здоров'я в Галичині наприкінці XIX на початку XX ст. [Електронний ресурс] / I. В. Білавич // 14. Медицина и фармацевтика: вчера, сегодня, завтра. - 30 с. - Режим доступу : http://www.sworld.com. ua/simpoz4/65.pdf.

2. Верхратський С. А. Історія медицини : навч. посіб. - 4-те вид., випр. і доповн. / С. А. Верхратський, П. Ю. Заблудовський. - К. : Вища школа, 1991. - 431 с. ; [Електронний ресурс] Режим доступу : http://www. bookish.link/istoriya-meditsiny/medichna-dopomogazahidnoukrajinskih-83793.html.

3. Ганіткевич Я. Історія української медицини в датах та іменах / Ярослав Ганіткевич. - Львів, 2004. - 365 с.

4. Голяченко О. Історія медицини : посіб. / О. Голяченко, Я. Ганіткевич. - 2-ге вид., доповн. - Тернопіль : ТДМУ, 2016. - 326 с.

5. Гонський Я. Іван Горбачевський в спогадах і листуванні / Я. Гонський. - Тернопіль : Укрмедкнига, 2004. $184 \mathrm{c}$.

6. Євген Озаркевич // Енциклопедія українознавства. Словникова частина / гол. ред. В. Кубійович. - Перевидання в Україні. - Львів : НТШ, 1996. - Т. 5. - С. 1831.

7. Клос Л. Є. Розвиток медичної освіти на західноукраїнських землях (друга половина XVIII - 30-ті роки

\section{References}

1. Bilavych, I.V. (2015). Stanovlennia i rozvytok hromadskoi systemy okhorony zdorovia v Halychyni naprykintsi XIX - na pochatku XX st. [Formation and development of public health care system in Halychyna in the late XIX - early XX century]. Meditsyna i farmatsevtika: vchera, segodnya, zavtra - Medicine and Pharmacology: Yesterday, Today, Tomorrow, 14, 30. Retrieved from http: // www.sworld.com.ua/simpoz4/65.pdf [in Ukrainian].

2. Verkhratskyi, S.A., \& Zabludovskyi, P.Yu. (1991). Istoriia medytsyny [History of medicine: textbook]. Kyiv: Vyshcha shkola. Retrieved from: http://www. bookish.link/istoriya-meditsiny/medichna-dopomogazahidnoukrajinskih-83793.html [in Ukrainian].

3. Hanitkevych, Ya. (2004). Istoriia ukrainskoi medytsyny $v$ datakh ta imenakh. NTSh [The history of the Ukrainian Medicine in dates and names]. Lviv [in Ukrainian]. of the graduates' educational level. As evidenced by many researchers, the Western Ukraine enjoys priority in regarding nursery as a peculiar medical sphere that requires proper theoretical and practical training. Comparative analysis of establishment and development of medical education in the Eastern and Western Ukraine in the second half of XVIIIXIX century may be regarded as a promising research area.

XX ст.) : автореф. дис. на здобуття наук. ступ. канд. пед. наук / Л. Є. Клос. - К., 2002. - 20 с.

8. Круківська I. М. Медична освіта на західноукраїнських землях: ретроспектива становлення (XIX - поч. XX ст.) / I. М. Круківська // Вісн. Житомир. держ. ун-ту ім. І. Франка. - 2005. - № 25. - С. 194-196.

9. Кушик М. Л. Організація медичної освіти в Україні в другій половині XIX - початку XX ст. [Електронний ресурс] / М. Л. Кушик // Педагогические науки/2. Проблемы подготовки специалистов. - Режим доступу : http://www. rusnauka.com/26_SSN_2008/Pedagogica/34933.doc.htm. 10. Медицина // Енциклопедія українознавства. Словникова частина / гол. ред. В. Кубійович. - Перевидання в Україні. - Львів : НТШ, 1996. - Т. 5. - С. 1506-1507.

11. Медична освіта // Енциклопедія українознавства. Словникова частина / гол. ред. В. Кубійович. - Перевидання в Україні. - Львів : НТШ, 1996. - Т. 5. C. $1509-1510$.

12. Наукові праці, документи і матеріали професора Івана Горбачевського: до 150-річчя від дня його народження / упор. і автор передм. І. Д. Головацький. - Львів, 2005. - 292 c.

13. Шапиро И. Я. Из истории медицинского образования в западных областях Украины и на Буковине / И. Я. Шапиро. - Львов : Изд-во Львов. ун-та, 1957. - 61 с.

4. Holiachenko, O., \& Hanitkevych, Ya. (2016). Istoriia medytsyny: posibnyk [History of medicine: manual]. (2nd ed.). Ternopil [in Ukrainian].

5. Honskyi, Ya. (2004). Ivan Horbachevskyi v spohadakh i lystuvanni [Ivan Horbachevskyi in memoirs and correspondence]. Ternopil: Ukrmedknyha [in Ukrainian].

6. Kubiiovych, V. (Ed.). (1996). Yevhen Ozarkevych. Entsyklopediia ukrainoznavstva. Slovnykova chastyna [Yevhen Ozarkevych. Encyclopedia of Ukraine. The vocabulary section]. Lviv: NTSh [in Ukrainian].

7. Klos, L.Ye. (2002). Rozvytok medychnoi osvity na zakhidnoukrainskykh zemliakh (druha polovyna XVIII 30-ti roky XX st.) [The development of medical education in the Western Ukrainian regions (the second part of the 18th - the thirties of the 20th century)]. Candidate's Extended abstract. Kyiv [in Ukrainian]. 
8. Krukivska, I.M. (2015). Medychna osvita na zakhidnoukrainskykh zemliakh: retrospektyva stanovlennia (XIX - poch. XX st.) [Medial Education in Western Ukrainian Lands: Retrospectives of Formation (XIX - early XX cent.)]. Visnyk Zhytomyrskoho derzhavnoho universytetu im. I Franka: Bulletin of Ivan Franko Zhytomyr State University, 25, 194-196 [in Ukrainian].

9. Kushyk, M.L. Orhanizatsiia medychnoi osvity v Ukraini v druhii polovyni XIX - poch. XX st. [The development of higher medical education in the late XIX - early XX century]. Pedahohicheskiye nauki. 2. Problemy podgotovki spetsyalistov-Pedagogical sciences. 2. The issues of specialists'training. Retrieved from: http://www.rusnauka. com/26__SSN_2008/Pedagogica/34933.doc.htm [in Ukrainian].

10. Kubiiovych, V. (Ed.). (1996). Medytsyna. Entsyklopediia ukrainoznavstva. Slovnykova chastyna
[Medicine. Encyclopedia of Ukraine. The vocabulary section]. Lviv: NTSh [in Ukrainian].

11. Kubiiovych, V. (Ed.). (1996). Medychna osvita. Entsyklopediia ukrainoznavstva. Slovnykova chastyna [Medical Education. Encyclopedia of Ukraine. The vocabulary section]. Lviv: NTSh [in Ukrainian].

12. Holovatskyi, I.D. (Ed.). (2005). Naukovi pratsi, dokumenty i materialy profesora Ivana Horbachevskoho: Do 150-richchia vid dnia ioho narodzhennia [Professor Ivan Horbachevsky's scientific works, documents and materials: dedicated to the 150th anniversary of his birth]. Lviv [in Ukrainian].

13. Shapiro, I.Ya. (1957). Iz istorii meditsinskogo obrazovaniya v zapadnykh oblastyakh Ukrainy i na Bukovine [From the history of medical education in the western regions of Ukraine and in Bukovina]. Lvov: Izd-vo Lvov. un-ta [in Russian].

E-mail address for correspondence: prokop@tdmu.edu.ua 